$$
\text { II. RÉSZ }
$$

\title{
A TISZTESSÉGTELEN KERESKEDELMI GYAKORLATOK SZABÁLYOZÁSA ÉS JOGGYAKORLATA
}





\title{
A TISZTESSÉGTELEN KERESKEDELMI GYAKORLATOK SZABÁLYOZÁSA ÉS GYAKORLATA CSEHORSZÁGBAN ${ }^{1}$
}

\author{
Simon Rita
}

\begin{abstract}
Debreceni Jogi Mühely, 2020. ÉVI (XVII. ÉVfolyam) I-2. DOI I $0.24 \mathrm{I} 69 / \mathrm{DJM} / 2020 / \mathrm{I}-2 / 6$
\end{abstract}

\section{Szabályozási keretrendszer}

A cseh jogalkotó az 1992 évi 634. számú fogyasztóvédelemről szóló törvénybe (a továbbiakban: CsFvt.) ${ }^{2}$ ültette át a tisztességtelen kereskedelmi gyakorlatokról szóló irányelvet (továbbiakban: 2005/29/EK irányelv) ${ }^{3}$ 2008-ban, de az átültetés nem volt teljes. ${ }^{4} \mathrm{~A}$ hiányos implementáció miatt számos rendelkezést nem ültettek át, például a „termék” fogalmát (amely kizárólagosan az árukra vonatkozott és nem tartalmazta a szolgáltatásokat), ${ }^{5}$ valamint olyan definíciókat, mint például a „vállalkozások és fogyasztók közötti kereskedelmi gyakorlatok”, „nem megengedett befolyásolás”, „felhívás vásárlásra” és „a fogyasztók gazdasági magatartásának jelentős torzítása”. Ezenkívül az irányelv időbeli alkalmazása - a kereskedelmi ügylet előtt, alatt és után - sem volt összhangban az irányelv 3. cikkének (1) bekezdésével, és néhány, fekete listás kereskedelmi gyakorlat is kimaradt a cseh törvényből: például az irányelv mellékletének 8., 11., 14. és 31. pontjai. Az Európai Bizottság 2014. január 23-án hivatalos értesítést küldött a hiányosságokról, ${ }^{6}$ amelynek következtében és a cseh jogalkotó módosította a törvényt, jóllehet a jogalkalmazók szerint számos hiányosságot orvosolni

1 A tanulmány megírása és megjelentetése az Igazságügyi Minisztérium jogászképzés színvonalának emelését célzó programjai keretében valósult meg.

2 2008. évi 36. számú törvény a fogyasztóvédelemről szóló 1992 évi 634. számú törvény módosításáról (Zákon č. 36/2008 Sb. kterým se méní zákon č. 634/1992 Sb., o ochranè spotŕebitele).

3 Az Európai Parlament és a Tanács 2005/29/EK irányelve (2005. május 11.) a belső piacon az üzleti vállalkozások fogyasztókkal szemben folytatott tisztességtelen kereskedelmi gyakorlatairól, valamint a 84/450/EGK tanácsi irányelv, a 97/7/EK, a 98/27/EK és a 2002/65/EK európai parlamenti és tanácsi irányelvek, valamint a 2006/2004/EK európai parlamenti és tanácsi rendelet módosításáról, HL L 149, 2005.6.11. 22-39.

4 R. Simon: Study to support the Fitness Check of EU Consumer law - Country report CZECH REPUBLIC. In: European Commission: Study for the Fitness Check of EU consumer and marketing law - Final report Part 3 -Country reporting. Brussels, 2017, 241-254.

5 Elkülönült definíció a CsFvt. 2. \$ (1) g pontja értelmében (Zákon č. 634/1992 Sb. o ochraně spotřebitele).

6 Lásd az Európai Bizottság 2014.1.23-án kelt 2013/2204. számú hivatalos értesítését. Ennek értelmében a Bizottság hiányosságokat állapított meg a 2., 3., 4., 5., 6. ,7. és 8., cikk kapcsán, valamint az I. számú függelék 8., 11. és 14. pontjaival kapcsolatban. Lásd szintén a 2514/11 számú EU-Pilot projektet (2011.12.15.) 
lehetett volna ún. „euro-konform” bírói jogértelmezéssel.7 A módosításoknak köszönhetően ${ }^{8}$ a jogalkotó magasabb szintre emelte a cseh törvény elöírásait, és 2015. december 28-tól a 2005/29/EK irányelv teljes egészében érvényesül a Cseh Köztársaságban.

A 2005/29/EK irányelv részben lehetőséget ad arra, hogy a tagállamok magasabb védelmi szintet biztosítsanak hazai fogyasztói számára, mint amit az irányelv minimálisan meghatároz a pénzügyi szolgáltatások és az ingatlanok vonatkozásában. Az irányelv a 3. cikk (9) bekezdése szigorúbb nemzeti követelményeket létrehozását engedélyezi, de a cseh jogalkotó nem élt ezzel a lehetőséggel. ${ }^{9}$ Másrészröl azonban a cseh jogalkotó részben kiterjesztette az irányelv alkalmazási körét a B2B tranzakciókra is, ami többlet szabály, igaz ezt nem az említett fogyasztóvédelmi törvénnyel érte el, hanem a Cseh Polgári Törvénykönyv ${ }^{10}$ 2976-2990. paragrafusaival (a továbbiakban: CsPtk.). A következő versenyt korlátozó cselekmények esetén fordulhatnak bírósághoz a versenytársak valamint a fogyasztók és kérhetik az elkövető felszólítását arra, hogy tartózkodjon a tisztességtelen versenycselekménytől, illetve szüntesse meg a jogsértő állapotot, vagy térítse meg az okozott károkat, illetve szolgáltassa ki az indokolatlanul szerzett előnyt: a) megtévesztő reklám, b) az áruk és szolgáltatások megtévesztő azonosítása, c) összetéveszthetőség okozása, d) a versenytárs termékének vagy szolgáltatásai jó hírnevének kihasználása, e) megvesztegetés, f) a versenytárs jó hírnevének veszélyeztetése, g) összehasonlító reklám, kivéve, ha az megengedhetö, h) üzleti titok megsértése, i) zaklatás, j) az egészség és a környezet veszélyeztetése. Ezek a szabályok az irányelv 11. cikkének (1) bekezdésére épülnek, és megteremtve a tisztességtelen kereskedelmi gyakorlatok révén keletkezett károk polgári jogérvényesítésének lehetőségét a Cseh Köztársaságban, amely sok szempontból különbözik a túldimenzionált közigazgatási jogérvényesítéstől. A napjainkban felmerülö újfajta tisztességtelen kereskedelmi gyakorlatok kapcsán, mint pl. a megtévesztő környezetvédelmi állítások, a cseh közigazgatási hatóságok vonakodnak attól, hogy alkalmazzák az irányelvet, illetve a létező cseh szabályokat.

7 A cseh Legfelsőbb Közigazgatási Bíróság 7 As 110/2014-52 számú, 2014.10.23-i határozata, továbbá lásd B. Vítová, M. Etlíková: Nekálé obchodni praktiky. Wolters Kluwer, Praha, 2017, 5.

8 2015. évi 378. számú törvény a fogyasztóvédelemről szóló 1992 évi 634. számú törvény módosításáról (Zákon č. 378/2015 Sb. kterým se méní zákon č. 634/1992 Sb., o ochrané spotrebitele).

9 A lakóingatlanokhoz kapcsolódó fogyasztói hitelmegállapodásokról, valamint a 2008/48/EK és a 2013/36/ EU irányelv és az 1093/2010/EU rendelet módosításáról szóló 2014/17/EU európai parlamenti és a tanácsi irányelv (továbbiakban: jelzálogkölcsön-irányelv) kapcsán nem volt egyértelmű, hogy a jogalkotó kíván-e magasabb szintű védelmet megvalósítani, mint amit az irányelv minimálisan elöírt.

10 2012. évi 89. számú törvény a Polgári törvénykönyvről (Zákon č. 89/2012 Sb. - Zákon občanský zákoník). 


\section{A tisztességtelen kereskedelmi gyakorlatokkal szembeni fellépés a Cseh Köztársaságban - kétirányú megközelítés}

A Cseh Köztársaságban mind a közigazgatási, mind pedig a polgári jogérvényesítés lehetősége fennáll a tisztességtelen kereskedelmi gyakorlat folytatóival szemben. Miután nem létezik kötelező jogérvényesítési sorrend, a jogérvényesítés útja a sértett személy választásától függ; de hangsúlyoznunk kell, hogy a választott jogérvényesítési út függvényében erőteljesen eltérő lehet az eljárási költségek nagysága, az eljárás időtartama és annak eredménye is. Közigazgatási jogérvényesítést a fogyasztók vagy fogyasztóvédelmi egyesületek kérelmére vagy hivatalból kezdeményezhet az illetékes hatóság; polgári jogi igények érvényesítése iránt pedig a fogyasztók, versenytársak, valamint a kereskedelmi vagy fogyasztóvédelmi egyesületek nyújthatnak be keresetet. Ha a jogosult közigazgatási eljárás megindítását kezdeményezi, akkor az eljárás a tisztességtelen kereskedelmi gyakorlatok folytatásának a megtiltását és közigazgatási bírság kiszabását eredményezheti, amely hatékony és visszatartó erejű szankció lehet más vállalkozással szemben is. A polgári eljárás során a bíróság eltilthatja a vállalkozást a tisztességtelen szerződési feltétel vagy kereskedelmi gyakorlat alkalmazásától, és elrendelheti az elszenvedett károk, ill. veszteségek megtérítését. Míg a közigazgatási eljárás ingyenes a fogyasztók és a fogyasztóvédelmi egyesületek számára, ${ }^{11}$ a polgári peres eljárásában a felperesre hárul a bírósági költségek fizetése, igaz a fogyasztóvédelmi és kereskedelmi egyesületek mentesíthetők a bírósági illetékek alól. Az illetékmentesség lehetősége azonban nem jelent teljes költségmentességet, ugyanis a polgári eljárás költségeit mindig a vesztes fél viseli, ezért egy esetleges pervesztés elviselhetetlen pénzügyi terhet hárít mind a fogyasztókra, mind a fogyasztóvédelmi egyesületekre. A polgári eljárásokkal kapcsolatos fó probléma, hogy a jogsértéstől való eltiltásra irányuló perben nem lehet igényelni a fogyasztók kárainak megtérítését; ezért a károsult fogyasztóknak külön keresetben kell folyamodniuk kártérítésért, ami a gyakorlatban nem fordul elő túl gyakran, mert a bizonyítási teher komoly nehézséget ró a fogyasztókra. Legnehezebb bizonyítani az elszenvedett kár nagyságát.

11 Távközlési ügyeknél a fogyasztónak legalább 100 CZK (kb. 3,70 EUR) eljárási díjat kell fizetnie, (másodfokon pedig mintegy 200 CZK-t (7,40 EUR), vagy a követelés értékének 4\%-át. Ez utóbbi elriaszthatja a fogyasztót a kereset benyújtásától, különösen alacsony értékủ ügyeknél. 
A Cseh Köztársaságban továbbra sem léteznek kollektív jogorvoslati mechanizmusok, amelyek lehetővé tennék, hogy károsult fogyasztók együttesen érvényesítsék igényeiket a tisztességtelen kereskedelmi gyakorlatok és a szerződési feltételek alkalmazóival szemben, jóllehet a jogalkotó 2016-ben megkezdte a kollektív cselekvésről szóló törvény előkészítését. ${ }^{12}$ A törvényjavaslatot már a kormány elé terjesztették, és a tervek szerint még 2020-ban ki is fogják hirdetni. A jövőbeni törvény azonban nagy kihívást fog jelenteni az egyébként is túlterhelt és kollektív mechanizmusokban járatlan bíróságok számára. ${ }^{13}$

\subsection{Közigazgatási eljárás - termék-alapú, mozaikszerü kompetenciák}

A közigazgatási igényérvényesítés fö előnyei az eljárási költségek hiánya, az eljárás gyorsasága és az eljárási szankciók. A Cseh Köztársaságban a CsFvt. 23. \$-a struktúrájának megfelelően több mint 17 hatóság felelős a fogyasztóvédelem végrehajtásáért. A kompetenciák megosztása „termék-alapú”. A feloszlás logikája szerint az a hatóság felel a tisztességtelen kereskedelmi gyakorlatok felügyeletéért, amelyik hatáskörébe tartozik az érintett termék vagy szolgáltatás piaca. A mozaikszerü kompetencia-felosztást a következő ábrával szemléltethetjük.

A kompetenciák megoszlása logikusnak tűnik, de a fogyasztók számára sokszor mégsem túl egyértelmü. ${ }^{14}$ Számukra sok esetben kihívást jelent, hogy megtalálják az eljárni jogosult hatóságot, és abban az esetben, ha a hatóság elutasítaná a kérelmet a hatáskör hiányára hivatkozva, nem kerül sor az ügy áttételre, ezért sok esetben megoldatlan fogyasztói kérelmekhez vezet a kompetencia-felosztás. A tisztességtelen kereskedelmi gyakorlatok felügyeletében a következő hatóságok a legfontosabbak a CsFvt. 23. \$-a értelmében a Cseh Kereskedelmi Felügyelet (az ábrán CTIA), de a Cseh Hírközlési Hatóság, a Cseh

12 A. Janoušková: Introduction to the new collective redress mechanism from the national legislator's perspective - class actions in the Czech Republic. In: R. Simon, H. Müllerová (eds.): Efficient Collective Redress Mechanisms in Visegrad 4 Countries: an Achievable Target? Institute of State and Law of the Czech Academy of Sciences, Praha, 2019, 72.

13 Hozzá kell tennünk, hogy a Cseh Köztársaságban a bírósági eljárások átlagos időtartama polgári perek esetén meghaladja a 3 évet.

14 A jelzálogkölcsön-irányelv átültetéséig a Cseh Nemzeti Bank csupán akkor volt illetékes a tisztességtelen kereskedelmi gyakorlatokkal összefüggő ügyekben, ha a pénzügyi intézmények voltak a jogsértők; a nem pénzügyi intézmények, például a HOMECREDIT esetében a Cseh Kereskedelmi Felügyelet volt kompetens. 2017-ben a nem pénzügyi intézmények is a Cseh Nemzeti Bank felügyelete alá kerültek. Lásd R. Simon: Správněprávní sankce za porušování spotřebitelských práv v České republice a Madarsku. In: L. Tichy (ed.): Ochrana Spotrebitele. PF Univerzita Karlova, Praha, 2014, 207. 


\section{TISZTESSÉGTELEN KERESKEDELMI GYAKORLATOK - CSEHORSZÁG}

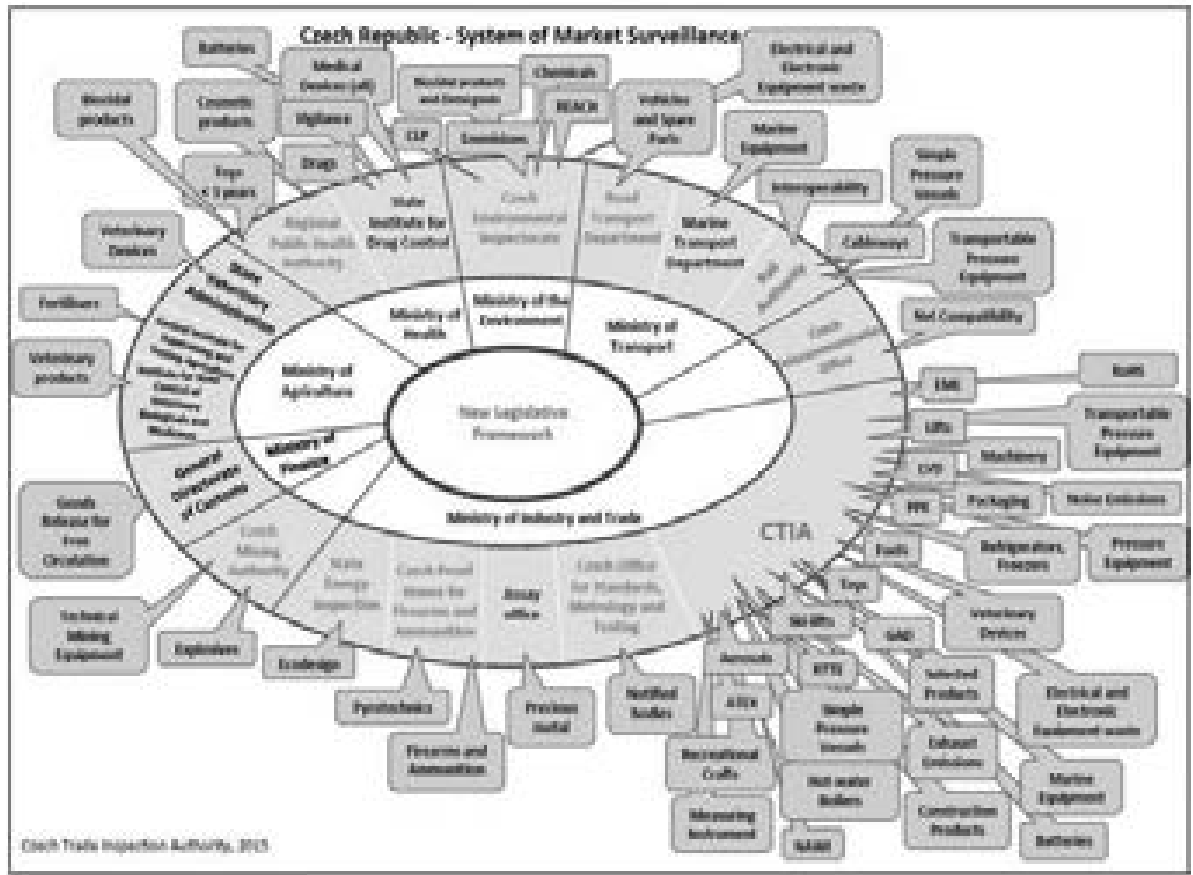

Tisztességtelen kereskedelmi gyakorlatok felügyelete a Cseh Köztársaságban

Forrás: Cseh Kereskedelmi Felügyelet ${ }^{15}$

Energiahatóság és a Cseh Nemzeti Bank, és az egyéb ágazatspecifikus szabályok felügyelete is ezen hatóságok hatáskörébe tartozik.

Mint már említettük, a közigazgatási eljárás hivatalból kezdeményezhető vagy a fogyasztóvédelmi egyesület, illetve a fogyasztó panasza, kérelme alapján indul. A fogyasztók évente kb. 20000 fogyasztói panaszt nyújtanak be a Cseh Kereskedelmi Felügyelethez. ${ }^{16}$ Miután a hatósági eljárás sui generis, az eljárást megindítására csak akkor kerül sor, ha a hatóság azt indokoltnak tartja. Az eljárás megindításának feltételeit az 2016 évi 255. számú, az ellenőrzésről szóló törvény 5 . \$-a határozza $\operatorname{meg}^{17}$, de a kritériumok, amelyek alapján a hatóság

15 M. Žiga: Market Surveillance in the Czech Republic. Czech Trade Inspection Authority, 16th Advisory Group on Market Surveillance (MARS Group) meeting Geneva, Switzerland, 27th June 2018, 14.

16 A Cseh Kereskedelmi Felügyelet által végrehajtott éves ellenőrzések száma meghaladja a 40 000-t. Lásd Ėves jelentés, elérhető: http://www.coi.cz/en/about-ctialannual-reports/annual-reports-on-ctia-activities/ (letöltés dátuma: 2020.02.10.)

172012 évi. 255. számú törvény az ellenőrzésről (Zákon č. 255/2012 kontrolni rád). 
dönt az eljárásról, nem nyilvánosak. Valamennyi hatóság követi ellenőrzések megszervezésére vonatkozó belső szabályokat, ${ }^{18}$ valamint az éves ellenőrzési tervet, ezen túl pedig akkor kerülhet sor eljárás megindítására, ha a Cseh Köztársaság és más tagállami hatóság közötti belső információcsere alapján az szükségesnek tünik. Az eljárás megindításáról a CsFvt. 26. \$-a értelmében csupán a fogyasztóvédelmi szervezetet kell értesítenie a hatóságnak, a kérelemtől számított 2 hónapon belül, a panaszos fogyasztót nem.

A szabálysértéssel kapcsolatos felelősségről és a szabálysértési eljárásról szóló 2016. évi 250. számú törvény ${ }^{19} 45-50$. \$-a értelmében (a továbbiakban: 250/2016. tv.) a hatóságok felszólíthatják, bírságolhatják a szabálysértést elkövető vállalkozást, továbbá felfüggeszthetik annak kereskedelmi tevékenységét, vagy elrendelhetik, hogy tegye közzé a közigazgatási határozatot. De ez a közzétételi szabály nem általános jellegü, tisztességtelen kereskedelmi gyakorlatokkal összefüggő ügyekben. Mivel a hatósági döntések általában nem érhetők el a nyilvánosság számára csupán néhány kulcsfontosságú közigazgatási bírósági határozat publikus a Cseh Köztársaságban - ezért a fogyasztóknak nincs információjuk a szabálysértési eljárás kimenetéről. Néhány hivatkozást a legfontosabb fogyasztóvédelmi szervezetek, például a dTest sajtóközleményeiben találhatnak az „informálódó” fogyasztók. ${ }^{20}$

Ami a fogyasztók szabálysértési eljárásban való közvetlen kártérítését illeti, meg kell jegyeznünk, hogy a jelenlegi szabályok értelmében a cseh hatóságok nem kötelezhetik a vállalkozást a tisztességtelen kereskedelmi gyakorlatok károsultjainak kárainak megtérítésére, amely gyakorlat erősen eltér a magyar, a lengyel és az Egyesült Királyság közigazgatási gyakorlatától. ${ }^{21}$ A cseh jogszabályok alapos vizsgálata után két elméleti lehetőséget mégis találunk a károsultak kárainak megtérítésére a szabálysértési eljárásban, de sajnos minden gyakorlati relevancia nélkül. Emellett a fogyasztó - elméletileg - bírósághoz is fordulhat, hogy a megállapított szabálysértés alapján kártérítést követeljen a vállalkozástól; mivel azonban a fogyasztó nem minősül „résztvevőnek” a közigazgatási eljárásban, akkor sem, ha az eljárás a panasza alapján indult, így valószínűleg arról sem fog

18 Lásd a Cseh Kereskedelmi Felügyelet által végrehajtott éves ellenőrzési tervet: https://www.coi.cz/wp-content/ uploads/2019/12/Program-dozoru-nad-trhem-2020.docx.pdf (letöltés dátuma: 2020.02.10.)

19 2016. évi 250. számú törvény a szabálysértéssel kapcsolatos felelősségről és a szabálysértési eljárásról (Zákon 250/2016 Sb. o odpovédnosti za prestupky a rízeni o nich).

20 www.dtest.cz (letöltés dátuma: 2020.02.10.)

21 R. Simon: More Efficient Collective Redress Mechanisms? Will the New Deal Directive on Representative Actions for Protecting the Collective Interests of Consumers Improve the Resolution of Mass Harm Situations in the Visegrad 4 Countries? European Review of Private Law, 2019/6, 1403. 


\section{TisZTESSÉGTELEN KERESKEDELMI GYAKORLATOK - CSEHORSZÁG}

értesülni, hogy a hatóság megállapította a szabálysértést a vállalkozással szemben. Ennek az a negatív következménye, hogy a fogyasztó nem tud egy esetleges kártérítési perben hivatkozni a szabálysértési határozatra, ami feleslegesen megduplázza az eljárási cselekményeket és bonyolítja a bizonyítást.

Közigazgatási eljárásban a következő két lehetőség nyílik a károk megtérítésére. Az első lehetőség az, hogy a károsult a 250/2016. tv. 70. \$ (2) bekezdése szerint bekapcsolódik a szabálysértési eljárásba és az első szóbeli meghallgatás előtt bejelenti kártérítést igényét az illetékes hatóságnak; a második lehetőség pedig a vállalkozó önkéntes kompenzációja. Ami az első lehetőséget illeti, a jogszabályok értelmében az eljáró hatóságnak értesítenie kell az ismert érintett személyeket az eljárásról, ha annak során kártérítés igénybevételére lenne lehetőség. Sajnos a legtöbb eljárás során ismeretlen marad a károsultak személye, illetve miután a közigazgatási hatóságok weboldaluk útján sem tájékoztatják megfelelően az esetlegesen károsultakat, és a vállalkozóra sem hárítanak ilyen irányú tájékoztatási kötelezettséget, így ezek az információk egyáltalán nem érik el a fogyasztót. A Cseh Kereskedelmi Felügyelet csak egyetlen esetet említett, amikor a fogyasztó sikeresen és időben benyújtotta kártérítési igényét a hatóságnál, régi ablakok cseréjével kapcsolatban. ${ }^{22}$ A kompenzáció második lehetősége, amikor a vállalkozó önként - saját kezdeményezésére - nyújt kompenzációt az eljárás során. Önkéntes kompenzáció esetén az illetékes hatóság köteles figyelembe venni az önkéntes vállalást a szankció kiszabásánál, és csökkentenie kell a bírság összegét. ${ }^{23}$ Noha a hatóságok nem kötelesek tájékoztatni a vállalkozásokat a károk önkéntes megtérítésének lehetőségéről, a gyakorlatban mégis előfordul jó néhány önkéntes teljesítés, de ezen esetek száma nem túl magas.

A 2005/29/EK irányelv aktuális módosításai miatt a jelenlegi cseh szabályozás nem maradhat változatlanul, ugyanis az Európai Parlament és a Tanács 2019/2161 irányelvének ${ }^{24}$ (továbbiakban: 2019/2161 irányelv) 11a. cikke elrendeli, hogy a tisztességtelen kereskedelmi gyakorlatok által megkárosított fogyasztók számára a tagállamok biztosítsanak arányos és hatékony jogorvoslati lehetőségeket, amit a hatályos szabályozás sem papíron sem a gyakorlatban nem garantál. A 2019/2161 irányelv által javasolt árcsökkentés vagy a szerződés

22 A szerző által a Cseh Kereskedelmi Felügyeletnél végzett 2020. február 5-i interjú alapján.

23 250/2016. tv. 87. \$-a és 39. \$-a.

24 Az Európai Parlament és a Tanács 2019/2161 irányelve (2019. november 27.) a 93/13/EGK tanácsi irányelvnek, valamint a 98/6/EK, a 2005/29/EK és a 2011/83/EU európai parlamenti és tanácsi irányelvnek az uniós fogyasztóvédelmi szabályok hatékonyabb végrehajtása és korszerűsítése tekintetében történő módosításáról, HL L 328., 2019.12.18., 7-28. 
felmondási jog biztosítása pedig különös kihivást jelent a jogalkotónak, ugyanis ilyen típusú jogorvoslati lehetőségek teljesen ismeretlenek a cseh közigazgatási gyakorlatban. Tekintettel arra, hogy a sértett fogyasztó megfelelő tájékoztatása nem működik kielégítően a jelenlegi rendszerben, ami a kártérítés előfeltétele, ezen szabályokra nézve is módosításokat várhatunk. Várhatóan a nemzeti hatóságok végrehajtási eszközei is bővülni fognak a közeljövőben, ugyanis a 2020. január 17-én hatályba lépett 2017/2394 rendelet (továbbiakban: 2017/2394 rendelet) ${ }^{25}$ 9. cikkének (4) bekezdése tágabb minimális eszköztárat ír elö, mint ami a cseh hatóságok rendelkezésére áll.

Annak ellenére, hogy közigazgatási eljárás során a fogyasztók kárait nem lehet közvetlenül megtéríttetni, a közigazgatási eljárás meghatározó szerepet játszik a tisztességtelen kereskedelmi gyakorlatokkal szembeni hatékony küzdelemben. A közelmúlt legproblémásabb kereskedelmi gyakorlatának elterjedését, az értékesítés céljából szervezett rendezvényeken történő eladást is csupán közigazgatási úton sikerült megállítani; ugyanis a jogellenes kereskedelmi gyakorlatokat nagyon nehézen lehetett bizonyítani bíróság előtt. Hiába fordultak bírósághoz a károsult fogyasztók, a polgári jogi eljárásban a magánautonómia elve érvényesült, így amennyiben a felek aláírták a szerződést, akkor az kötelezte őket. Ha azonban a kereskedelmi felügyelet felügyelője értesült egy ilyen termékbemutató rendezvényről, akkor a hatósági eszközökkel könnyebben meg tudta akadályozni az értékesítést. A cseh jogalkotó 2013-ban elrendelte, ${ }^{26}$ hogy az ilyen típusú termékbemutató rendezvényeket előzetesen be kell jelenteni a Cseh Kereskedelmi Felügyeletnél, ideértve a rendezvény tervezett idejét, helyszínét és a felkínált termékek jellegét is. 2015-ben a jogalkotó tovább bővítette a bejelentésre kötelezett információk listáját, és elöírta, az áruk árának bejelentését is, és megtiltotta, hogy az eladó a rendezvény során előleget vagy bármilyen díjat fogadjon el a fogyasztótól. ${ }^{27}$ A Cseh Kereskedelmi Felügyelet gyors és mélyreható ellenőrzésinek köszönhetően csökkentek a termékbemutató rendezvények és a cseh piac ezen szegmensében jelenleg nincsenek feketelistás üzleti gyakorlatok. ${ }^{28}$

25 Az Európai Parlament és a Tanács (EU) 2017/2394 rendelete (2017. december 12.) a fogyasztóvédelmi jogszabályok végrehajtásáért felelős nemzeti hatóságok közötti együttműködésről és a 2006/2004/EK rendelet hatályon kívül helyezéséről, HL L 345., 2017.12.27., 1-26.

26 CsFvt. 20. $\$$

27 CsFvt. 20b. $\$$

28 R. Simon: i.m., 2017, 242. 


\section{TisZTESSÉGTELEN KERESKEDELMI GYAKORLATOK - CSEHORSZÁG}

\subsection{Bírósági jogérvényesítés}

A tisztességtelen kereskedelmi gyakorlatok által okozott károk polgári jogi érvényesítése nagyon bonyolult, és a gyakorlatban egyáltalán nem fordul elő a Cseh Köztársaságban. Ennek oka az, hogy a cseh polgári eljárásjogból hiányoznak a kompenzációs elemekkel tarkított actio popularis keresetek, hasonlóan az ún. follow-on kártérítési igényekhez és a kollektív kártérítési keresetekhez. Ha a fogyasztó a tisztességtelen kereskedelmi gyakorlat által okozott kárának megtérítését szeretné elérni, akkor először panasszal kell folyamodnia a kereskedőhöz, majd sikertelen panaszkezelés esetén egyéni keresetet kell benyújtania a polgári bírósághoz. A bírósági eljárásban a fogyasztó a polgári jog általános elveinek sérelme alapján kérheti a tisztességtelen kereskedelmi gyakorlat megszüntetését, pl. mert azért, mert a gyakorlat sérti a tisztességes kereskedés elvét vagy a közrendet. ${ }^{29}$ Ezenkívül a fogyasztó azzal is érvelhet, hogy tévedésben volt a vásárlási döntésnél. ${ }^{30}$ Bármelyik érvelést is választja a fogyasztó, a bizonyítási teher nehézsége, az eljárás költségvonzata és hossza, valamint a jogsértés és a kár közötti okozati összefüggés bizonyításának bonyolultsága miatt, elhanyagolható számú esetet találunk a bírói gyakorlatban. ${ }^{31}$ Elmondhatjuk, hogy sem a korábbi, sem a 2014 óta hatályos CsPtk. alapján nem részesítik előnyben a fogyasztók a polgári jogérvényesítést a tisztességtelen kereskedelmi gyakorlatok által okozott káruk megtérítésére.

Ahogyan korábban már említettük, 2014. január 1-jétől hatályos új PTK megteremti a megtévesztő reklám, az összehasonlító reklám, valamint az áruk és szolgáltatások megtévesztő identifikációja során keletkezett károk polgári jogi érvényesítését a fogyasztók és a versenytársak javára. A CsPtk. 2988 \$-a értelmében „Az a személy, akinek a jogát a tisztességtelen versenycselekmény veszélyeztette vagy megsértette, kérheti a jogsértöt, hogy tartózkodjon a tisztességtelen versenytôl, vagy távolitsa el a hibás állapotot". Ebben az esetben nemcsak kártérítés igényelhető, hanem a veszteségek megtérítésére és az jogalap nélküli gazdagodás visszatérítésére is. A tisztességtelen versennyel kapcsolatos polgári keresetek nagy részét a gyakorlatban a versenytársak nyújtják be; a fogyasztók egyáltalán nem, pedig a bizonyítási terhet illetően jobb helyzetben lennének, mint más keresetek során. Ugyanis a CsPtk. 2989. §-ának (2) bekezdése megfordítja a bizonyítási

29 CsPtk. 580. $\$$

30 Lásd B. Vítová, M. Etlíková: i.m, 66-76., CsPtk. 583. \$

31 A cseh Legfelsőbb Közigazgatási Bíróság 23 Cdo 3704/2011 számú és 23 Cdo 4669/2010 számú határozata. 
terhet és a jogsértőnek kell bebizonyítania, hogy nem sértette meg tisztességtelen módon a versenyt, és hogy a keletkezett kárt nem a tisztességtelen verseny okozta. Ezen a szabályok kifejezetten progresszívek, igaz a fogyasztók kompenzációjában egyelőre nem játszanak szerepet. Nehéz lenne megjósolni, hogy vajon mennyiben bővül ezen szabályok alkalmazása a jövőben a 2019/2161 irányelv 3. cikkének (5) bekezdésének implementációja miatt, de mindenképpen kívánatos lenne, hogy a jogalkalmazók és a fogyasztók felismerjék a szabályban rejlő lehetőségeket.

A nem kért értékesítés esetén (ha egy vállalkozó a fogyasztó megrendelése nélkül szállít valamilyen terméket, és a fogyasztó azt birtokba veszi), jóhiszemü birtokosnak kell tekinteni a fogyasztót; de a fogyasztó nem köteles visszaadni a kéretlen terméket a vállalkozónak saját költségén. ${ }^{32}$ Az új szabállyal 2014 óta csupán két bírósági határozat foglalkozott. ${ }^{33}$

2016 februárja óta a fogyasztók bíróságon kívüli békéltetető eljárást is kezdeményezhetnek a CsFvt. 20d. \$-a értelmében, feltéve, hogy a fogyasztónak nem sikerült rendezni a panaszt a kereskedővel. Érdekes módon a cseh jogalkotó többnyire ugyanazokat a közigazgatási hatóságok bízta meg az alternatív vitarendezés működtetésével, mint amelyek ellátják a tisztességtelen kereskedelmi gyakorlatok felügyeletét. A cseh kormány csupán a pénzügyi szolgáltatások vitarendezésére hozott létre egy független alternatív vitarendezési testületet. A pénzügyi ombudsman, amelynek hivatala 2011-óta müködik, ${ }^{34}$ a Cseh Távközlési Felügyelethez és a Cseh Energiahivatalhoz hasonlóan, kötelező érvényű vitarendező megoldást is elöírhat. Ultima ratio békéltető testületként a jogalkotó a Cseh Kereskedelmi Felügyeletet ${ }^{35}$ jelölte ki, amelyhez évente mintegy 3500-4000 békéltetési kérelmet nyújtanak be a fogyasztók. Érdekes módon ez az egyetlen olyan békéltető testület a négy működő testület közül, amely nem hozhat kötelező erejü békéltető határozatot. ${ }^{36}$

Összességében megállapíthatjuk, hogy a tisztességtelen kereskedelmi gyakorlat során bekövetkezett kár megtérítésére a cseh fogyasztóknak egyéni jogorvoslatot kell igénybe venniük a bíróságtól, amely nagyon hosszú és költséges megoldás, és kiszámíthatatlan eredménnyel jár, pontosan ezért a kb.

32 CsPtk. 1838. $\$$

33 Prága Megyei Bíróság 22 Co $177 / 54$ számú határozata, és a Český Budějovic-i Megyei Bíróság 10 A 181/2014 - 69 számú határozata.

34 https://www.finarbitr.cz/en/ (letöltés dátuma: 2020.02.10.)

35 https://www.coi.cz (letöltés dátuma: 2020.02.10.)

36 Lásd a Cseh Kereskedelmi Felügyelet éves jelentéseit, mely letölthetö: https://www.coi.cz/wp-content/ uploads/2019/04/web_COI_vyrocni_zprava_2018-2.pdf(letöltés dátuma: 2020.02.10.) 


\section{TiszTességTelen KERESKEDELMI GYAKORLATOK - CSEHORSZÁG}

10000 CZK (390 EUR) értékű kár alatt a fogyasztók vonakodnak ettől a megoldástól és vagy alternatív vitarendezési eljárást kezdeményeznek, vagy tétlenek maradnak. A tisztességtelen verseny károsultjai számára az új CsPtk. végre alkotott néhány új polgári jogorvoslati mechanizmust, kérdéses azonban, hogy mennyiben fogják alkalmazni a fogyasztók ezeket a mechanizmusokat. Mindaddig, amíg a cseh polgári eljárásban hiányozni fognak a kollektív igényérvényesítési mechanizmusok, addig várhatóan alacsony szintű marad a tisztességtelen kereskedelmi gyakorlatok által okozott károk megtérítése. Ezekkel a mechanizmusokkal Csehország alig fog megfelelni a 2017/2394 rendelet követelményeinek, és a 2019/2161 irányelv is hozhat újításokat.

\section{A fogyasztói szervezetek különleges jogállása a tisztességtelen kereskedelmi gyakorlatok elleni fellépésnél}

A cseh fogyasztóvédelmi egyesületek előtt mindkét jogérvényesítési út nyitva áll a tisztességtelen kereskedelmi gyakorlatok elleni fellépésre, a cseh fogyasztóvédelmi törvény szerint. A CsFvt. 25. \$-ának (2) bekezdése értelmében egyrészt polgári keresetet nyújthatnak be az egyesületek a kereskedelmi gyakorlat tisztességtelenségének megállapítására, ami a gyakorlatban nagyon ritka keresetfajta; vagy pedig a CzCPA 26 . \$-a szerint közigazgatási eljárást kezdeményezhetnek, szuper-panaszosként (super compliant). Mivel ez utóbbi beavatkozás sokkal olcsóbb és gyorsabb megoldás, és nem ró semmilyen bizonyítási terhet az egyesületre, ez utóbbi jogérvényesítési mechanizmus uralkodó a Cseh Köztársaságban.

\subsection{A fogyasztóvédelmi egyesület közigazgatási kérelme}

Ha egy fogyasztóvédelmi szervezet tisztességtelen kereskedelmi gyakorlatok megvalósítását feltételezi, de nincs elegendő bizonyítéka arra, hogy megállapítási kereset nyújtáson be, közigazgatási kérelmet küldhet az illetékes piacfelügyeleti hatósághoz. Az illetékes hatóság ugyan nem köteles megindítani az eljárást, de minden esetben köteles indokolatlan késedelem nélkül - legkésőbb 2 hónapon belül - értesíteni az egyesületet a megtett eljárási intézkedésekről. A fogyasztóvédelmi egyesületek dicsérik a hatóságokkal való együttműködést, igaz, nem minden hatóság reagál ugyanolyan pozitívan a fogyasztóvédelmi egyesület panaszaira. A vállalkozások pedig általában azonnal reagálnak 
a közigazgatási szerv intézkedésére, mert a közigazgatási szankció erős motiváció. A közigazgatási eljárás figyelemre méltó szerepet játszik a kollektív fogyasztói érdeksérelmek megakadályozásában, ugyanis a nemzeti hatóságok felügyeleti tevékenysége messze túlmutat egy egyszerü ellenőrzési eljáráson. Az eljárás igazi eredménye, hogy a vállalkozás valóban változtat üzleti gyakorlatán. ${ }^{37} \mathrm{~A}$ sikeres adminisztratív intézkedés egyik példája, mikor a Távközlési Felügyelet betiltotta a UPC „garantált árakkal örökké” reklámját, amellyel a UPC 2013-ban az árak rögzítését ígérte a fogyasztóinak, holott az Általános Szerződési Feltételek egyike kifejezetten feljogosította az UPC-t arra, hogy egyoldalúan megváltoztassa árait. Ez a határozat jelentős visszhangot kapott a médiában. ${ }^{38}$

Az adminisztratív intézkedésekkel kapcsolatban egyetlen hiányosságot kell felrónunk, mégpedig azt, hogy a hatóságok egyáltalán nem alkalmazzák azokat a rendelkezéseket, amelyekkel kompenzálhatnák a sérült fogyasztók kárait.

\subsection{A jogsértés megszüntetésére irányuló bírósági eljárások}

Annak ellenére, hogy Csehországban is átültetették a jogsértés megszüntetésére irányuló eljárásokról szóló irányelvet, ${ }^{39}$ és az idő folyamán még az eljárás kezdeményezőinek a személyi körét is bővítették; a jogsértés megszüntetésére irányuló eljárások nem játszanak releváns szerepet. Az elmúlt 15 évben csupán kb. 12 keresetet nyújtottak be a feljogosított szervezetek, amelyből az Európai Bizottság legfrissebb, 2019-es közleménye ${ }^{40}$ szerint Csehországban mindössze hat volt. ${ }^{41}$

2003 és 2008 között az SOS fogyasztóvédelmi egyesület tíz jogsértés megszüntetésére irányuló keresetet nyújtott be a bíróságokhoz, amelyek például az ASKO bútorház, a Sky Europe Airlines, az Eurocom Group és az Exim Tours ellen irányultak. Mivel a vitát bíróságon kívüli megegyezéssel sikerült rendezni

37 R. Simon: i.m., 2019, 1408.

38 https://www.ctu.cz/tiskova-zprava-milionova-pokuta-upc-za-klamavou-obchodni-praktiku (letöltés dátuma: 2020.02.10.)

39 Az Európai Parlament és a Tanács 2009/22/EK irányelve (2009. április 23.) a fogyasztói érdekek védelme érdekében a jogsértés megszüntetésére irányuló eljárásokról, HL L 110., 2009.5.1., 30-36.

40 A Bizottság értesítése a fogyasztói érdekek védelme érdekében a jogsértés megszüntetésére irányuló eljárásokról szóló, a 98/27/EK irányelvet kodifikáló 2009/22/EK európai parlamenti és tanácsi irányelv 4. cikkének (3) bekezdése tekintetében az irányelv 2. cikkének hatálya alatt jogsértés elleni eljárás indítására feljogosított egységekről. HL C 237., 2019.7.15., 3-68.

41 Az alábbi hat szervezet: 1. Sdružení českých spotřebitelů, z. ú, 2. dTesto. p. s., 3. Sdružení obrany spotřebitelů - Asociace, z. s, 4. Společná obrana, z. s, 5. Unicampus 6. HELP - Sdružení práv podvedených (HELP Cheated Consumers' Rights Association). 


\section{TisZTESSÉGTELEN KERESKEDELMI GYAKORLATOK - CSEHORSZÁG}

- ami a kereset preventív hatását bizonyítja - az SOS fogyasztóvédelmi egyesület a legtöbb esetben visszavonta keresetét. Más pereket, pl. a Kasa.cz ${ }^{42}$ elleni „ajándékkártya” pert, amelyben az SOS azt kifogásolta, hogy az ajándékkártya lejárta után nem téríti vissza a vállalkozó a kártya vételárát, az egyesület elvesztette. Miután az eljárás költségei (beleértve az ügyvédi díját is) jelentős gazdasági terhet rónak a szervezetre, ez volt az utolsó jogsértés megszüntetésére benyújtott keresete, többre nem volt elegendő forrása. Hasonló negatív tapasztalatokról számolt be a dTest is, a jelenleg legaktívabb cseh fogyasztóvédelmi egyesület. Másodfokon már vonakodott benyújtani az Unicredit Bank ellen bankszámlák díjköltségeivel kapcsolatos ${ }^{43}$ keresetét a bírósághoz, mert egy esetleges pervesztés csődbe vitte volna az egyesületet.

A legutóbbi jogsértés megszüntetésére irányuló kereset, egy megoldhatatlan hatásköri vitával végződött. A keresetet a dTest nyújtotta be 2016. július 15én az $\mathrm{O} 2$ ellen, annak érdekében, hogy az $\mathrm{O} 2$ valóban tartsa be a „korlátlan internetes szolgáltatást" ígéretét, ahogy azt hirdette, miközben a szolgáltatás az ÀSZF értelmében korlátozott volt. Prága 4. számú Városi Bírósága, amelynek hatásköre lett volna erre a speciális keresetre, július 18-án kompetencia hiánya miatt elutasította a keresetet. ${ }^{44}$ Döntésében a távközlési törvény 129 . \$-ának (5) bekezdésére ${ }^{45}$ hivatkozott, amelynek értelmében a Cseh Hírközlési Hatóság rendelkezik kizárólagos hatáskörrel a távközlési szerződésekkel kapcsolatos jogvitákra nézve. Igaz, hogy ez a norma valóban quasi-bírósági hatáskört biztosít a Cseh Távközlési Hatóságnak, a jogsértés megszüntetésére irányuló keresetek a cseh $\mathrm{PP}^{46} 83 . \$(2)$ bekezdésének b) pontja szerint továbbra is bírósági hatáskörbe tartoznak. Miközben a fellebbviteli bíróság előtt folyt a vita, a cseh jogalkotó a távközlési törvény módosításával megoldotta a hatásköri kérdés, mialatt az O2 változtatott a távközlési kampányon.

Ezek az esetek azt mutatják, hogy a jogsértés megszüntetésére irányuló keresetek - ellentétben az európai jogalkotó szándékával - fogatlan oroszlánoka Cseh Köztársaságban. A keresetek benyújtását elsősorban a fogyasztóvédelmi szervezetek pénzügyi forráshiánya akadályozza. A pervesztés ugyanis

42 A cseh Legfelsőbb Közigazgatási Bíróság 33 Cdo 1956/2007 számú határozata.

43 Prága 4 Városi Bíróság 7C 308/2013-140. számú határozata.

44 Prága 4 Városi Bíróság 40 C 196/2016-48. számú határozata.

45 A 2005 évi 127. számú törvény az elektronikus kommunikációról (Zákon č. 127/2005 Sb. o elektronických komunikacích).

46 Az 1963. évi 99. számú törvény a polgári eljárásról (Zákon č. 99/1963 Sb. občanský soudní rád). 
fizetésképtelenséget okozhat a fogyasztóvédelmi egyesületnek. A költségek megtérítésének alternatív megoldása nem megoldható, mert sem állami források nem állnak rendelkezésre, sem külső forrásokat sem vonhatnak be az egyesületek. A cseh szabályok azt sem teszik lehetővé, hogy a jogsértés megszüntetésére irányuló kereseteket összevonják a fogyasztók kártérítési kereseteivel. Pedig a kompenzációs igények és a jogsértés megszüntetésére irányuló keresetek összekapcsolása jelentősen megnövelné a keresetfajta jelentőségét, ám ehhez jogszabályi módosításokra volna szükség. A tisztességtelen kereskedelmi gyakorlatok bíróság előtti megtámadásának további problémája, hogy nagyon nehezen bizonyíthatók az agresszív kereskedelmi gyakorlatok, a megtévesztő mulasztásról nem is beszélve.

A hazai nehézségek ismeretében valószínűleg nem meglepő, hogy a feljogosított fogyasztóvédelmi egyesületek egy másik EU-s országban sem nyújtanak be jogsértés megszüntetésére irányuló kereseteket. Egy másik tagállamban indított per még bonyolultabb, kockázatosabb és költségesebb lenne az egyesület számára, és speciális jogi ismereteket igényelne.

\section{Szankciók és pénzbírságok a tisztességtelen kereskedelmi gyakorlatok alkalmazóival szemben}

A szabálysértéssel kapcsolatos felelősségről és a szabálysértési eljárásról szóló törvény ${ }^{47} 35$. \$-a ötféle szankció kiszabását tesz lehetővé az közigazgatási hatóságok számára, amely szankciók kombinálhatók egymással: a) figyelmeztetés kisebb szabálysértés esetén; b) bírságolás; c) tevékenység végzésének megtiltása; d) a dolog vagy értékvesztésének megtérítése, e) a szabálysértési határozat közzététele. Az általános hatósági gyakorlat szerint a piacfelügyelet minden esetben pénzbírságot szab ki, ha jogsértés észlel. A maximálisan kiszabható bírság összege tisztességtelen kereskedelmi gyakorlatok esetén 5 millió CZK (kb. 185000 EUR) a CsFvt. 24. $\$(14)$ bekezdésének d) pontja értelmében. Az egyedi bírság konkrét szintjét a 2017-ig, a korábban hatályos CsFvt. 24b. §-ának megfelelően a következő kritériumok alapján határozták meg a hatóságok: a szabálysértés súlya és módja, annak körülményei és következményei. Mivel a kiszabott bírságok mértéke a múltban erősen különbözött, attól függően, hogy a melyik piacfelügyeleti hatóság, mely térségben hozta a határozatot, a jogalkotó a 250/2016. tv. 37-40. \$-ával egyesítette a bírságok kiszabásának elveit. Így 2017 januárja óta valamennyi

47 A 2016. évi 250. törvény (Zákon o odpovédnosti za prestupky a rízení o nich). 


\section{TisZTESSÉGTELEN KERESKEDELMI GYAKORLATOK - CSEHORSZÁG}

hatóságnak ugyanazokat az elveket kell követnie. A tisztességtelen kereskedelmi gyakorlatok vonatkozásában, mely azt jelenti, hogy a piacfelügyeleti hatóságoknak a korábbi kritériumok mellett - figyelembe kell venniük: a szabálysértés jellegét; a kereskedelmi tevékenységének jellegét; azt, hogy a cselekmény egy vagy több szabálysértést valósított-e meg; a szabálysértésből származó azon előnyök mértékét, amelyből az ügyvezető igazgató részesült, valamint, hogy a cselekmény folyamatos, tartós vagy kollektív szabálysértést valósított-e meg. A bírság összegének kiszabásakor figyelembe kell venni az ún. súlyosbító és enyhítő körülményeket, például, hogy a kereskedő mennyiben térítette meg önkéntesen a bekövetkezett fogyasztói károk. A kritériumok listája nem kimerítő. Miután a törvény rögzíti ezeket a kritériumokat, így a bírság kiszabásának szempontjai előzetesen megismerhetők a vállalkozások számára. A kiszabott bírság megalapozottságát számtalan vállalkozás megkérdőjelezte, így igen fejlett a közigazgatási bíróságok joggyakorlata. Már a korábbi, azaz a 2017 előtti ítéletek is behatóan foglalkoztak azzal a kérdéssel, hogy a közigazgatási hatóság mennyire vizsgálta a bírság kivetésekor a szabálysértés jellegét, módját, intenzitását, időtartamát, annak következményeit és a károk megtéríthetőségét. ${ }^{48}$ Számos határozat foglalkozott a bírság mérséklésének feltételeivel is. A bírósági határozatok egyöntetűen kihangsúlyozták, hogy a bírságok ideális szintjének megállapítása nem bírói feladat, ez a közigazgatási hatóságok feladata, a bíróság csupán a szankcionálás kritériumainak alkalmazását vizsgálhatja. ${ }^{49}$ Ami a kivetett bírságok átlagos mértékét illeti, a gyakorlatban leggyakrabban 100000 CZK (kb. 3900 EUR) összegü bírságokkal találkozunk, kivételesen $450000 \mathrm{CZK}$ (kb. 17500 EUR) összegűvel, ami nagyon messze van a kivethető maximális bírság mértékétől. ${ }^{50}$

Noha a cseh bírságolási szabályok nem biztosítanak kivételes elbánást a kisés középvállalkozók számára, a kisebb vállalkozások esetében kiemelkedően fontos az az alapelv, amely értelmében a kiszabott bírság nem okozhat likviditási nehézséget. A Legfelsőbb Közigazgatási Bíróság ítélkezési gyakorlata szerint, ${ }^{51}$ amennyiben a kiszabott bírság fizetésképtelenséget okozna a jogsértő vállalkozásnak, akkor a bírság mérsékléséért kell folyamodnia és aktívan bizonyítania kell a teher elviselhetetlenségét. ${ }^{52}$ Meggyőző bizonyítékok nélkül nem engedélyezhető a bírság csökkentés.

48 A cseh Legfelsőbb Közigazgatási Bíróság 4 As 51/2007-68. számú és 8 As 8/2005-57. számú határozata.

49 A cseh Legfelsőbb Közigazgatási Bíróság 7 As 22/2012-23. számú határozata.

50 A cseh Legfelsőbb Közigazgatási Bíróság 9 Af 6/2010-52. számú határozata.

51 A cseh Legfelsőbb Közigazgatási Bíróság 1 As 9/2008-133. számú határozata.

52 A cseh Legfelsőbb Közigazgatási Bíróság 30 A 146/2016 - 56. számú határozata 


\section{Együttmüködés más tagállami hatóságokkal a tisztességtelen kereskedelmi gyakorlatok leküzdése érdekében}

Mivel a tisztességtelen kereskedelmi gyakorlatok nem állnak meg a nemzeti határokon, sok esetben más európai országban található kereskedők alkalmaznak tisztességtelen kereskedelmi gyakorlatot. Külföldi székhelyű vállalkozások ellen a cseh piacfelügyeleti hatóság kétféleképpen folytathat le közigazgatási eljárást: más tagállamban is foganatosíthat eljárási cselekményt, vagy felkérhet más tagállami hatóságot, hogy hajtsa végre a szükséges eljárási cselekményt. Mindkét esetre ismerünk példákat, bár az effajta intézkedések száma továbbra is nagyon alacsony. A Cseh Kereskedelmi Felügyelet öt olyan esetről számolt be az elmúlt három évben, amikor önállóan tett közigazgatási intézkedést egy külföldi kereskedővel szemben, például egy svájci székhelyű online társkereső szerver, a VIAGOGO-val szemben, és néhány érmegyűjtő szolgáltató ellen. Gyakoribb azonban, hogy a Felügyelet a CPC-hálózatot hívja segítségül. 2019-ben a Cseh Kereskedelmi Felügyelet nyolc segítségnyújtási kérelmet küldött más tagállami hatósághoz közigazgatási intézkedésekre, és 7 megkeresést fogadott. Az ilyen típusi eljárások végrehajtása általában hat hónaptól egy évig terjed.

\section{Magatartási kódexek szerepe a tisztességtelen kereskedelmi gyakorlatok megakadályozásánál}

Az önszabályozásnak a kommunista időszak előtt nagy hagyománya volt a Cseh Köztársaságban, majd félbeszakadt a gyakorlata. ${ }^{53}$ Manapság egyre több új kezdeményezést figyelhetünk meg, például az Elektronikus Kereskedelmi Szövetség (APEK) E-shop kódexét, ${ }^{54}$ de hasonló kezdeményezések száma még mindig nagyon alacsony. A meglévő etikai kódexek csak korlátozott számú vállalkozásra érvényesek, mivel sem a kamarai sem az egyesületi tagság nem kötelező Csehországban. Általánosságban elmondható, hogy azok a kereskedők, amelyek valamilyen egyesületekhez csatlakoztak, jobban aggódnak jó hírnevükért és pontosan ezek azok a vállalkozások, akik igyekeznek elkerülni a tisztességtelen kereskedelmi gyakorlatokat. Azok a vállalkozások azonban, amelyek nem tántorodnak vissza tisztességtelen kereskedelmi gyakorlatoktól, általában semmilyen egyesületnek sem tagjai.

53 R. Simon: i.m., 2017.

54 https://www.apek.cz/kodex-terminologie-lhut-dodani (letöltés dátuma: 2020.02.10.) 


\section{TISZTESSÉGTELEN KERESKEDELMI GYAKORLATOK - CSEHORSZÁG}

Néhány esetben a hatóságok is igyekeznek aktívan befolyásolni a kereskedők önszabályozását, például a Cseh Távközlési Hatóság rendszeresen közzéteszi a tisztességes szerződési feltételeiről és kereskedelmi gyakorlatokról szóló ajánlásait a távközlési szolgáltatók részére. ${ }^{55}$ Néhány önszabályozási norma létezik a pénzügyi szektorban is, például a „ügyfélmobilitási” kódex, amely a kliensek bankszámlaváltást igyekszik megkönnyíteni, de ez nem igazi önszabályozási norma. ${ }^{56}$

\section{Fogyasztói modellek a bírósági gyakorlatban}

Az „átlagfogyasztó” nem volt releváns referenciapont az eredeti cseh fogyasztóvédelmi törvényben, ám a 2016. évi törvénymódosítások új szabályokat vezettek be, amelyek hivatkozási pontnak tekintik a csoport átlagos tagját, azon kereskedelmi gyakorlatok esetén, amelyek egy bizonyos csoportra irányulnak. ${ }^{57}$ A Kereskedelmi és Ipari Minisztérium szakértői hangsúlyozták, hogy a törvény 4. $\$$-ának (1) bekezdése az átlagfogyasztóra utal, még akkor is, ha a norma nem használja ezt a kifejezést. ${ }^{58}$

A fogyasztói modelleket a cseh kommentárok sem tárgyalják behatóan. ${ }^{59}$ A három fóbb CsPtk. kommentár egyike sem említ fogyasztói modelleket a CsPtk. 419. \$-a szerinti „fogyasztó” fogalmának vonatkozásában. A fogyasztóvédelemről szóló törvény kommentárja sem tárgyal normatív fogyasztói modelleket, sem pedig az EUB által alkalmazott fogyasztói modelleket. ${ }^{60}$

A joggyakorlat is csak elvétve említi az átlagfogyasztót, konkrét fogyasztói modellek még nem kristályosodtak ki a cseh bírósági gyakorlatban. ${ }^{61}$ A leggyakrabban a védjegyjogban találkozunk az átlagfogyasztóval, ${ }^{62}$ ahol

55 Az ajánlás 48 oldalas, letölthetö: http://www.ctu.cz/doporuceni-ctu-k-navrhum-smluv-o-poskytovani-verejnedostupnych-sluzeb-elektronickych-komunikaci (letöltés dátuma: 2020.02.10.)

56 Miután ezt az Európai Bizottság nyomására fogadták el a tagállamok.

57 CsFvt. 4. $\$$

58 Lásd a cseh Legfelsőbb Közigazgatási Bíróság 3 As 29/2007. számú és 8 As 83/2010. számú határozatát, valamint a Legfelsőbb Bíróság 23 Cdo 784/2010. számú határozatát.

59 A három legfontosabb kommentár egyike sem említi a fogyasztói modelleket a CsPtk. $\$ 419$ "fogyasztó" paragrafusnál.

60 Attól függően, hogy az ítélet a tisztességtelen versenyt vagy a szerződéses jogot érinti-e. Lásd R. Sik-Simon: Fogyasztókép és szabályozás, MTA Law Working Paper, Budapest, 2/2016.

61 Lásd J. Jedlinský: Koncept prưmérného spotrebitele v českém a evropském právu. Právnická Fakulta Univerzity Karlovy, 2012.; M. Kousalová: Koncept prưmèrného spotrebitele. Univerzita Karlova v Praze Právnická Fakulta, Diplomová práce, 2013.

62 A cseh Legfelsőbb Közigazgatási Bíróság 23 Cdo 3773/2010. számú és 23 Cdo 4384/2008. számú és 32 Cdo 3895/2007. számú határozata. 
a bíróság a különféle márkák megkülönböztethetősége kapcsán vizsgálta az átlagfogyasztói szemléletet. Sok esetben ezt, a védjegyjogi fogyasztói „modellt” alkalmazzák a bíróságok a kereskedelmi gyakorlatok vagy a szerződéses jogviták kapcsán is. ${ }^{63}$ A bírói gyakorlat másik fó tendenciája az, hogy a bíróság konkrét elemzés nélkül idézi az EUB gyakorlatát: „Manapság szigorúbban kell megítélni az átlagfogyasztó képességeit, nem a felületes, szokásos figyelmet tanúsító fogyasztóból kell kiindulni”. ${ }^{64}$ Néhány ítélet megemlíti, hogy „a referenciaérték az az átlagfogyasztó, aki észszerüen tájékozott, figyelmes és körültekintő, figyelembe véve a társadalmi, kulturális és nyelvi tényezőket, ahogy azt az EUB értelmezte”. ${ }^{65}$

A felületes cseh joggyakorlat azonban nem veszi figyelembe, hogy az EUB különböző fogyasztói modelleket alkalmaz tisztességtelen verseny és szerződéses viták kapcsán. ${ }^{66}$ Ennek folytán a cseh bíróságok viszonylag magas szellemi potenciált várnak el az átlagfogyasztótól, ami egy túlidealizált fogyasztói modellhez vezet, ami igen messze van a potenciális átlagfogyasztótól, és közvetetten a védelmi szint csökkentéséhez vezet. Ezzel a jelenséggel elsősorban az alsóbb szintű bíróságokon találkozunk: „A fogyasztót nem kényszerül arra, hogy szerződéses kapcsolatra lépjen a szolgáltatóval. Csak rajta múlik, hogy megismerje az ÀSZF-ek feltételeit; gondosan átgondolja, hogy szerződéses kapcsolatra lép-e a vállalkozóval”. ${ }^{67}$ „A fogyasztóvédelem nem értelmezhető úgy, hogy saját gondatlanságától és a felelőtlenségétől kell megvédenünk a fogyasztót. (...) A szerződéses kapcsolatokban elvárható, [...] hogy minden személynek meg legyen az átlagos ismerete, valamint az a képessége, hogy körültekintéssel járjon el; ezért jogilag mindenkitől elvárható, hogy teljesítse azt a szerződést, amit aláírt." Hasonló érveléssel például a Prága 8 Városi Bírósága elutasította a kereskedelmi gyakorlat tisztességtelenségének megállapítását, egy szokványos edénykészlet eladása kapcsán, annak ellenére, hogy az edénykészletet termékbemutató rendezvényen - nagy rábeszéléssel - adták el egy idős személynek, mintegy 35000 CZK-ért (150 EUR), holott a készlet átlagos piaci ára max. 2000 CZK lehetett. ${ }^{69}$

63 A cseh Legfelsőbb Bíróság 33 Odo 930/2006. számú határozata és a cseh Legfelsőbb Közigazgatási Bíróság 6A 61/2002-52. számú határozata.

64 A cseh Legfelsőbb Bíróság 23 Cdo 4384/2008. számú és 32 Cdo 3895/2007. számú határozata.

65 A cseh Legfelsőbb Bíróság 32 Cdo 3895/2007. számú határozata.

66 R. Simon: Spotřebitelské modely v evropském a českém právu $-s$ ohledem na smluvně právní spory. Právnik, 2018/5. 385-406.

67 A cseh Legfelsőbb Bíróság 33 Cdo 2675/2007. számú és 32 Cdo 191/2014. számú határozata.

68 Prága 8 Városi Bíróság 12C 317/2013. számú határozata.

69 Prága 8 Városi Bíróság 12C 317/2013. számú határozata. 


\section{TisZTESSÉGTELEN KERESKEDELMI GYAKORLATOK - CSEHORSZÁG}

A bírósági döntések sérülékeny fogyasztói csoportokat sem definiálnak. Még a Proenzi-ügyben ${ }^{70}$ sem nevesített a Legfelsőbb Bíróság sérülékeny fogyasztói csoportot, pedig étrend-kiegészítők megtévesztő reklámozása volt a jogvita tárgya. A bíróság elzárkózott attól, hogy sérülékenynek minősítse a betegek csoportját és kimondta, hogy az átlagfogyasztó képes megkülönböztetni az étrendkiegészítők és a gyógyszerek hatását. ${ }^{71}$ Egy másik ügy kapcsán, a prágai városi bíróság ugyan „befolyásolhatóbbnak” minősítette a beteg személyek csoportját, a reklámban szereplő készítmény preventív gyógyító hatásának vizsgálatakor, itt sem minősítette a betegeket sérülékenynek. ${ }^{72} \mathrm{Az}$ ellenőrző hatóságok gyakrabban alkalmazzák a sérülékeny fogyasztói modellt, mint a bíróságok. A Cseh Kereskedelmi Felügyelet és a Cseh Hírközlési Hatóság sok esetben sérülékenynek minősíti a gyermekeket, a terhes nőket és/vagy a nyugdíjasokat. Arra azonban még a közigazgatási hatóságok sem vállalkoznak, hogy sérülékeny fogyasztónak minősítsenek eladósodottakat vagy szegényeket, holott Csehországban több mint 800000 természetes személy ellen folyik jelenleg végrehajtási eljárás. ${ }^{73}$

\section{Kitekintés - jövőben várható módosítások?}

A tisztességtelen kereskedelmi gyakorlatok megakadályozására a Cseh Köztársaságban mind a közigazgatási, mind a polgári jogérvényesítí út igénybe vehető, a gyakorlatban a fogyasztók mégis inkább a közigazgatási végrehajtást részesítik előnyben. A közigazgatási jogérvényesítés fö pozitívuma az eljárás gyorsasága és alacsony költségigénye, valamint a visszatartó erejű pénzbírságok. A közigazgatási hatóságok aktív ellenőrzési tevékenységeknek köszönhetően jelenleg a cseh gyakorlatban nem találunk feketelistás tisztességtelen kereskedelmi gyakorlatokat. A közigazgatási eljárások egyetlen hiányossága, hogy a fogyasztó nem részesülhet kártérítésben, pedig a hatályos szabályok lehetővé teszik a kompenzációt. A hatóságoknak sokkal bővebb tájékoztatást kellene nyújtaniuk ahhoz, hogy a fogyasztó értesülhessen a hatósági ellenőrzési tevékenységéről, és kártérítésért tudjon folyamodni az adminisztratív eljárásban.

70 A cseh Legfelsőbb Bíróság 32 Cdo 1721/2012. számú határozata.

71 A cseh Legfelsőbb Bíróság 32 Cdo 1721/2012, számú határozata, lásd M. Kousalová: i.m.

72 Prága Városi Bíróság 11 A 94/2018- 52. számú határozata.

73 https://www.irozhlas.cz/zpravy-domov/exekuce-osobni-bankrot-oddluzeni-zmeny-statistika_1905280745_kno (letöltés dátuma: 2020.02.10.) 
Hatékony kártérítés azonban bírósági úton sem biztosított. A bírói jogérvényesítés elősegítése érdekében kollektív jogorvoslati mechanizmusokra lenne szükség és biztosítani kell a jogsértés megszüntetésére irányuló keresetek finanszírozhatóságát, máskülönben a fogyasztóvédelmi egyesületek a jövőben sem lesznek képesek arra, hogy bírói úton állítsák meg a tisztességtelen kereskedelmi gyakorlatokat. Továbbá lehetővé kell tenni azt is, hogy a jogsértés megszüntetésére irányuló eljárásban kompenzálják a tisztességtelen kereskedelmi gyakorlat révén károsult fogyasztókat. A 2019/2161 irányelv és a 2017/2394 rendelet további kihívásokat hárítanak a cseh jogalkotóra, mivel a cseh közigazgatási gyakorlatban teljesen ismeretlenek az olyan típusú magánjogi jogorvoslati mechanizmusok, mint pl. az árcsökkentés vagy a szerződés felmondása. Remélhetőleg a jogalkotó megragadja az implementáció nyújtotta lehetőségeket és olyan mechanizmusokat vezet be, amelyekkel valóban meg lehet állítani a tisztességtelen kereskedelmi gyakorlatokat. 


\section{Forrásjegyzék}

1. A. JanoušKová: Introduction to the new collective redress mechanism from the national legislator's perspective - class actions in the Czech Republic. In: R. Simon, H. Müllerová (eds.): Efficient Collective Redress Mechanisms in Visegrad 4 Countries: an Achievable Target? Institute of State and Law of the Czech Academy of Sciences, Praha, 2019, 69-78.

2. J. JeduinskÝ: Koncept prưmérného spotřebitele v českém a evropském právu. Právnická Fakulta Univerzity Karlovy, 2012.

3. M. Kousalová: Koncept prưmèrného spotréebitele. Univerzita Karlova v Praze Právnická Fakulta (Diplomová práce), 2013.

4. R. Sik-Simon: Fogyasztókép és szabályozás, MTA Law Working Paper, Budapest, 2/2016.

5. R. Simon: More Efficient Collective Redress Mechanisms? Will the New Deal Directive on Representative Actions for Protecting the Collective Interests of Consumers Improve the Resolution of Mass Harm Situations in the Visegrad 4 Countries? European Review of Private Law, 2019/6. 1389-1410.

6. R. Simon: Spotřebitelské modely v evropském a českém právu - s ohledem na smluvně právní spory. Právník, 2018/5. 385-406.

7. R. Simon: Správněprávní sankce za porušování spotřebitelských práv v České republice a Madarsku. In: L. Tichy (ed.): Ochrana Spotrebitele. PF Univerzita Karlova, Praha, 2014, 207-222.

8. R. Simon: Study to support the Fitness Check of EU Consumer law Country report CZECH REPUBLIC. In: European Commission: Study for the Fitness Check of EU consumer and marketing law - Final report Part 3 - Country reporting. Brussels, 2017, 241-254.

9. B. VÍtovÁ, M. Etlíková: Nekálé obchodni praktiky. Wolters Kluwer, Praha, 2017.

10. M. ŻIGA: Market Surveillance in the Czech Republic. Czech Trade Inspection Authority, 16th Advisory Group on Market Surveillance (MARS Group) meeting Geneva, Switzerland, 27th June 2018.

11. Az Európai Parlament és a Tanács 2005/29/EK irányelve (2005. május 11.) a belső piacon az üzleti vállalkozások fogyasztókkal szemben folytatott tisztességtelen kereskedelmi gyakorlatairól, valamint a 84/450/EGK 
tanácsi irányelv, a 97/7/EK, a 98/27/EK és a 2002/65/EK európai parlamenti és tanácsi irányelvek, valamint a 2006/2004/EK európai parlamenti és tanácsi rendelet módosításáról, HL L 149, 2005.6.11. 22-39.

12. Az Európai Parlament és a Tanács 2009/22/EK irányelve (2009. április 23.) a fogyasztói érdekek védelme érdekében a jogsértés megszüntetésére irányuló eljárásokról, HL L 110., 2009.5.1., 30-36.

13. Az Európai Parlament és a Tanács 2014/17/EU irányelve (2014. február 4.) a lakóingatlanokhoz kapcsolódó fogyasztói hitelmegállapodásokról, valamint a 2008/48/EK és a 2013/36/EU irányelv és az 1093/2010/EU rendelet módosításáról, HL L 60., 2014.2.28., 34-85.

14. Az Európai Parlament és a Tanács (EU) 2017/2394 rendelete (2017. december 12.) a fogyasztóvédelmi jogszabályok végrehajtásáért felelős nemzeti hatóságok közötti együttműködésről és a 2006/2004/EK rendelet hatályon kívül helyezéséről, HL L 345., 2017.12.27., 1-26.

15. Az Európai Parlament és a Tanács 2019/2161 irányelve (2019. november 27.) a 93/13/EGK tanácsi irányelvnek, valamint a 98/6/EK, a 2005/29/ EK és a 2011/83/EU európai parlamenti és tanácsi irányelvnek az uniós fogyasztóvédelmi szabályok hatékonyabb végrehajtása és korszerüsítése tekintetében történő módosításáról, HL L 328., 2019.12.18., 7-28.

16. A Bizottság értesítése a fogyasztói érdekek védelme érdekében a jogsértés megszüntetésére irányuló eljárásokról szóló, a 98/27/EK irányelvet kodifikáló 2009/22/EK európai parlamenti és tanácsi irányelv 4. cikkének (3) bekezdése tekintetében az irányelv 2. cikkének hatálya alatt jogsértés elleni eljárás indítására feljogosított egységekről. HL C 237., 2019.7.15., 3-68.

17. Az 1963. évi 99. számú törvény a polgári eljárásról (Zákon č. 99/1963 Sb. občanský soudni rád).

18. 1992. évi 634. számú törvény a fogyasztóvédelemről (Zákon č. 634/1992 Sb., o ochranè spotrébitele)

19. A 2005 évi 127. számú törvény az elektronikus kommunikációról (Zákon ć. 127/2005 Sb. o elektronických komunikacích).

20. 2008. évi 36. számú törvény a fogyasztóvédelemről szóló 1992 évi 634. számú törvény módosításáról (Zákon č. 36/2008 Sb. kterým se mèni zákon č. 634/1992 Sb., o ochranè spotřebitele).

21. 2012. évi 89. számú törvény a polgári törvénykönyvről (Zákon č. 89/2012 Sb. - Zákon občanský zákoník). 


\section{TisZTessÉGTELEN KERESKEDELMI GYAKORLATOK - CSEHORSZÁG}

22. A 2012 évi. 255. számú törvény az ellenőrzésről (Zákon č. 255/2012 kontrolní rád).

23. 2015. évi 378. számú törvény a fogyasztóvédelemről szóló 1992 évi 634. számú törvény módosításáról (Zákon č. 378/2015 Sb. kterým se mèni zákon č. 634/1992 Sb., o ochraně spotřebitele).

24. A 2016. évi 250. törvény (Zákon o odpovédnosti za prestupky a řizeni o nich)

25. Legfelsőbb Bíróság 33 Odo 930/2006. számú határozata

26. Legfelsőbb Bíróság 33 Cdo 2675/2007. számú határozata

27. Legfelsőbb Bíróság 32 Cdo 3895/2007. számú határozata

28. Legfelsőbb Bíróság 23 Cdo 4384/2008. sz. határozata

29. Legfelsőbb Bíróság 23 Cdo 784/2010. számú határozata

30. Legfelsőbb Bíróság 32 Cdo 1721/2012. számú határozata

31. Legfelsőbb Bíróság és 32 Cdo 191/2014. sz. határozata

32. Legfelsőbb Közigazgatási Bíróság 6A 61/2002-52. számú határozata

33. Legfelsőbb Közigazgatási Bíróság 8 As 8/2005-57. számú határozata

34. Legfelsőbb Közigazgatási Bíróság 3 As 29/2007. számú határozata

35. Legfelsőbb Közigazgatási Bíróság 4 As 51/2007-68. számú határozata

36. Legfelsőbb Közigazgatási Bíróság 33 Cdo 1956/2007 számú határozata

37. Legfelsőbb Közigazgatási Bíróság 1 As 9/2008-133. számú határozata

38. Legfelsőbb Közigazgatási Bíróság 23 Cdo 4384/2008. számú határozata

39. Legfelsőbb Közigazgatási Bíróság 9 Af 6/2010-52. számú határozata

40. Legfelsőbb Közigazgatási Bíróság 8 As 83/2010. számú határozata

41. Legfelsőbb Közigazgatási Bíróság 23 Cdo 3773/2010. számú határozata

42. Legfelsőbb Közigazgatási Bíróság 23 Cdo 4669/2010 számú határozata

43. Legfelsőbb Közigazgatási Bíróság 23 Cdo 3704/2011 számú határozata

44. Legfelsőbb Közigazgatási Bíróság 7 As 22/2012-23. számú határozata

45. Legfelsőbb Közigazgatási Bíróság 7 As 110/2014-52 számú határozata

46. Legfelsőbb Közigazgatási Bíróság 30 A 146/2016 - 56. számú határozata

47. Prága 4 Városi Bíróság 7C 308/2013-140. számú határozata

48. Prága 4 Városi Bíróság 40 C 196/2016-48. számú határozata

49. Prága 8 Városi Bíróság 12C 317/2013. számú határozata

50. Cseh Kereskedelmi Felügyelet éves jelentése, elérhető: http://www.coi.cz/ en/about-ctialannual-reports/annual-reports-on-ctia-activities) (letöltés dátuma: 2020.02.10.) 
51. Cseh Távközlési Hatóság ajánlása, elérhető: http://www.ctu.cz/doporuceni-ctuk-navrhum-smluv-o-poskytovani-verejne-dostupnych-sluzeb-elektronickychkomunikaci (letöltés dátuma: 2020.02.10.)

52. Elektronikus Kereskedelmi Szövetség (APEK) E-shop kódexe, elérhető: https://www.apek.cz/kodex-terminologie-lhut-dodani (letöltés dátuma: 2020.02.10.)

53. https://www.coi.cz/wp-content/uploads/2019/04/web_COI_vyrocni_ zprava_2018-2.pdf_(letöltés dátuma: 2020.02.10.)

54. https://www.ctu.cz/tiskova-zprava-milionova-pokuta-upc-za-klamavouobchodni-praktiku (letöltés dátuma: 2020.02.10.)

55. https://www.irozhlas.cz/zpravy-domov/exekuce-osobni-bankrot-oddluzenizmeny-statistika_1905280745_kno

56. www.dtest.cz (letöltés dátuma: 2020.02.10.)

57. https://www.finarbitr.cz/en/

58. https://www.coi.cz 
Dr. Simon Rita, LL.M, BA, 2017 óta a Cseh Tudományos Akadémia Állami és Jogi Intézetének, valamint 2011-től a prágai Károly Egyetem Összehasonlító Jogi Központjának a kutatója. Kutatási területe a fogyasztóvédelem és versenyjog összehasonlító (jogi) szempontú vizsgálata. Amellett, hogy számos szakcikk szerzője, a Cseh Köztársaság előadója az Európai Bizottság nyomonkövetési jelentéseiben, nemzetközi kutatócsoportok tagja, továbbá oktat a Károly Egyetemen a fogyasztóvédelem különféle aspektusairól. A mobilitási projekt vezetője (MTA 19-10, 2019-2021 között) a Magyar Tudományos Akadémia közreműködésével megvalósult „A fogyasztó fogalmának és normatív meghatározásának felülvizsgálata” című kutatásban, továbbá a „A kollektív jogorvoslati mechanizmusok fejlődésének vizsgálata a környezetvédelmi és fogyasztói tömeges károkozások tekintetében, a Nemzetközi Visegradi Alapítvány finanszírozásával megvalósult „Visegrad 4” projekt [IVF 21730099] véglegesítésében is részt vett. Jogi tanulmányait a budapesti ELTE jogi karán végezte, versenyjogi doktori fokozatot szerzett a Kölni Egyetemen (2005). Különböző német intézményekben dolgozott, például Bonnban az Európai Integrációs Tanulmányok Központjában és a Kölni Egyetem Kelet-európai Jogi Intézetében, továbbá a magyar Igazságügyi Minisztérium Polgári Jogi Kodifikációs Irodájának volt munkatársa. 